\title{
Applied Agrarian Import Ban and its Impact on Mutual Trade among Russian Federation and European Union \& other Selected Countries
}

\author{
Luboš SMUTKA, Michal STEININGER \\ Czech University of Life Sciences Prague, Prague, Czech Republic \\ \{smutka, steininger\} @pef.czu.cz
}

\begin{abstract}
Paper's goal is to provide an overview of Russian import ban impact on trade between Russian Federation and USA, Canada, Australia, Norway and especially EU countries. The paper identifies the changes affecting especially EU agrarian exports performance in relation to Russian Federation. There're changes identified in trade in vegetables, fruits, meat and animal products, dairy and dairy products and fish. There're following findings in the paper: The result of the applied import ban was a significant reduction of Russian agrarian import value (within the first three years alone, the value of imports was reduced by 7,389 million USD). Applied ban affected especially those imports which could be understand as competitors for national production capacities. The potential to substitute those items by local production is evident. The applied ban affected imports especially from Lithuania, Germany, the Netherlands, Denmark, Spain, Belgium, Finland and France. Speaking about the most affected countries, in relation to the share of Russian imports in their trade performance, the most affected countries are Lithuania, Latvia, Estonia, Finland and Poland. To satisfy domestic demand Russia increased food imports especially from Serbia, China, Azerbaijan, Ecuador, Kyrgyzstan, India, Macedonia, Georgia, Bosnia and Malaysia. The negative feature of applied ban especially for Russian consumers was the reduction of food heterogeneity, the growth of food price, the reduction of competitiveness and available food quality reduction.
\end{abstract}

Keywords: Russian Federation, Agrarian Import Ban, European Union.

\section{Introduction}

Russian food import ban must be understood not only as political answer for Western countries applied sanctions and criticism, but it is also the result of long-run Russian food security and food independency policy [9]. While in period $1991-2005$ the volume and value of national food production were decreasing, the value and volume of imports were constantly increasing. The result of such development was constantly increasing negative agri-food trade balance [12]. In transformation period especially, export commodity structure became more concentrated into only few especially bulk commodities. Import profile became very heterogeneous and because of low import 
prices it represented the significant barrier for Russian agricultural sector recovery [7]. Already in period before the import ban was applied Russian government was seeking for the arguments to protect its market and the increase national food security [2]. Western countries sanctions provided arguments for Russian government to apply its plans supporting expansion of domestic agricultural sector. The applied import ban supported the original Russian government's Doctrine of Food Security of RF [13]: grain $-95 \%$ self-sufficiency, sugar $-80 \%$ self-sufficiency, vegetable oil $-80 \%$ selfsufficiency, meat and meat products $-85 \%$ self-sufficiency, milk and dairy products $90 \%$ self-sufficiency, fish products $-80 \%$ self-sufficiency, potatoes $-95 \%$ selfsufficiency, edible salt $-85 \%$ self-sufficiency). Applied ban affected import of vegetables, fruits, animal and dairy products and fish products. The Russian agrarian import ban has been extended and changed several times since 2014.

The impact evaluation of the Russian embargo from the Russian and foreign point of view has been considered in recent studies. A regression-based analysis revealed that sustainability of the food supply in Russia is threatened by inflation and a degrading purchasing power of the population from people shifting towards cheaper products of lower quality, while exporters seek higher profits outside the country and thus create food shortages in the domestic market [3]. The most promising new strategy to overcome the prospective crisis could be an increase of food products to Asian and African countries [10].

To cover the food shortage, Russia started or expanded collaboration with other partners of the world, e.g. Brazil, Belorussia, Paraguay, Argentina and Iran (meat), Ecuador, Pakistan, Morocco, China (fruit), Egypt, Republic of South Africa, Israel, Azerbaijan (vegetables) etc. [8].

The goal of this paper is to provide an overview of Russian import ban impact on trade between Russian Federation and affected countries. Because of applied ban character, the European Union could be considered as the most affected subject of Russian protectionism. The paper identifies the changes affecting especially EU agrarian exports performance in relation to Russian Federation. Changes in trade in vegetables, fruits, meat and animal products, dairy and dairy products and fish are identified. Paper also deals with changes in Russian trade competitiveness and territorial structure.

\section{Data and Methods}

This paper is focused to provide an overview of applied Russian import ban impact on the first set of countries (Australia, Canada, European Union, Norway, United States of America). Those countries' agricultural trade is affected by Russian import ban for last five years (2014-2018) and it is expected that import ban will be in force until at least 2019. During the last few years the list of countries and items under the ban increased. Because of data availability, this paper has been analysing the impact of applied ban on original countries and changes in their agricultural trade performance and Russian territorial structure are analysed for the period 2014-2016. 
The basic sources of data for the analysis are Federal Customs Service of Russia [5], Federal State Statistics Service of RF [6], UN Comtrade [1] and FAO UN [4]. Data involved into the analyses is organized according to Harmonized Commodity Description and Coding System (HS) of the World Customs Organisation.

The paper is analysing changes in commodity structure value and volume development. Separately are analysed items affected by applied ban and trade in items not affected by import ban. The most affected commodity aggregations are the following: meat and meat products, milk and dairy products, vegetable and fruit and fish.

The processed data are analysed through the set of the following instruments (for the possibility to compare the real impact of import ban - the same methodology is for the paper [11] is applied):

Self-sufficiency ratio (SSR). The level of self-reliance for certain types of agricultural products is determined by the percentage of agricultural production, to the consumption of the country.

$$
S S R=\frac{\text { Production }}{\text { Amounts of Domestic Supply }}
$$

Import dependency ratio (IDR). In the course of analysis of the food situation of a country, an important aspect is to know how much of the available domestic food supply has been imported, and how much comes from the country's own production.

$$
I D R=\frac{\text { Imports }}{\text { Amounts of Domestic Supply }}
$$

\section{Results and Discussion}

Agriculture represents the significant pillar for Russian rural areas development. Nearly $25 \%$ of population are living in rural areas, nearly $7 \%$ of economically active population are working in agriculture. Agricultural population is representing about 10$15 \%$ in total population. Agriculture is also extremely important for development of local infrastructure and some other externalities.

Russian federation has been suffering the significant import dependency especially in the case of vegetables, fruits, meat and dairy products and fish and crustaceans. The applied import ban is not random one. Ban is applied exactly in relation to those commodity items representing the weakness of Russian agriculture and foodstuff market. The potential to increase production capacity and performance is significant. The only problem to increase self-sufficiency and production performance is competitiveness and limited cost efficiency. The applied ban provides the possibility to develop local production capacities and performance. There are two by side affects related to applied ban. The first effect is political one increasing independency and the support of national production capacities. The second one is related to economic issues - reduction of consumer surplus, increasing food price and reduction of agrarian trade 
deficit. Russian government is interested to change the existing disbalance between agrarian imports ( $12.5 \%$ of total imports) and exports (5\% of total exports) in relation to total merchandise trade performance.

The idea of the following analysis is to identify the impact/efficiency of applied ban on Russian agrarian trade in relation to countries affected by applied ban.

In 2016, the total value of Russian food imports decreased by $42 \%$ in relation to 2013. The value of imports of products under the ban reduced during the analysed period by $57 \%$.

Already the first year of applied ban affected significantly mutual trade between Russian Federation and banned countries. If we compare Russian import value of banned products in 2013 (9,007 million USD) and the value performance one year late (2014), it is possible to see the significant reduction by 3,888 million USD (but ban was applied only for last five months). One year later (2015), the applied ban already reduced imports of banned products by another 4,247 million USD (in comparison to previous year). In 2016, imports of banned products from affected countries reached only 742 million USD. It means that applied ban reduced mutual trade between Russia on one side and EU, Australia, Canada, Norway, USA on the opposite side by nearly $92 \%$.

As a consequence of the sanctions being applied, the share of the banned countries' food products as a proportion of the total Russian food imports steadily declined. In the period 2014-2016 alone, their share reduced from cc $44 \%$ to cc $25 \%$. The most affected subject of applied sanctions is the European Union. In the period before the sanctions, the share of the EU in Russian imports of subsequently banned food products was nearly $15 \%$, while in 2016 it was only $2.73 \%$ (exports to Russia reduced by 5.8 billion USD). Sanctions also affected Norway (exports to Russia reduced by 1.1 billion USD).

The value of meat exports reduced from 2.282 billion USD to 536 million USD, the value of fish exports reduced from 1.55 billion USD to 64 million USD, the value of milk and milk product exports reduced from 1.78 billion USD to 4.3 million USD, the value of vegetable exports reduced from 946 million USD to 59 million USD, the value of fruit exports reduced from 1.76 billion USD to 70 million USD, and the value of food preparations exported reduced from 679 million USD to 487 million USD. The countries of the European Union can be considered as the main loser of the applied Russian import ban policy.

As a result of the import ban, the share of selected countries in Russian agrarian imports of products under the ban reduced (2013 vs. 2016). The applied import ban had already affected individual countries in 2014 (the first year of sanctions). In 2014 alone, the share of the EU in Russian imports affected by ban reduced from $28 \%$ to $17 \%$, and the share of Norway had reduced from 5\% to 3\%. During 2015 and 2016 the share of individual countries affected by the ban in Russian imports of products reduced even more. In 2016 the share of EU reached only $6.8 \%$, the share of Norway reduced to $0.001 \%$, the share of Canada reached only $0.003 \%$, the share of the USA reduced to $0.58 \%$, and the share of Australia reduced to only $0.0001 \%$.

Russian federation was not able to substitute banned imports from local sources for $100 \%$. The significant part of banned items import was necessary to substitute by imports from under countries (not included into ban list). While the share of affected 
countries in Russian imports of banned products was reduced from cc $21 \%$ to only $3 \%$, the share of other countries increased from cc $30 \%$ to $37 \%$.

EU export of banned items was reduced from 6.5 billion USD to less than 700 million USD. Between 2013 and 2016, the total value of EU exports of vegetables to Russia decreased by $94 \%$ in terms of value, and by $95 \%$ in terms of quantity. The most affected products were tomatoes (decreased by 199 thousand tonnes), cabbages (decreased by 118 thousand tonnes), carrots (decreased by 91 thousand tonnes), and potatoes (decreased by 80 thousand tonnes). The most affected countries by applied ban are the following: the Netherlands, Spain, Poland and Belgium. On the other hand, the winners of applied ban are China, Turkey, Belarus, and Egypt. Those countries manage to replace European exports to Russia especially in the case of tropical and subtropical production. It means the applied ban not only reduced EU's exports of its own production, but it also affected re-exports.

In the first place, the Russian ban affected the perishable products/fruit sector. Russia represented about $30 \%$ of the EU's fruit exports in 2013. The main products concerned were apples, peaches, nectarines and pears. The main EU suppliers of fruits were Poland, Spain, Greece, Italy and Belgium. In period 2013 - 2016, European fruit export was reduced from 1,519 million USD to nearly 70 million USD. The value of exports was reduced by $95 \%$ and export volume was reduced by $97 \%$ (from 1538 to 40 tons). The most affected countries by ban were the following: the Netherlands, Spain, Italy, Poland and Germany. From Russian perspective, the majority EU's exports were replaced Turkey, Belarus and Serbia. Belarus and Serbia dispose bilateral trade agreements in relation to Russian Federation. Because of import ban, their role as countries supplying Russian market increased especially because of their re-exports.

Another item significantly affected by Russian import ban is represented by Meat and meat products EU's exports. The volume and value of exported meat were reduced by nearly $100 \%$. The value of exports reduced from 1,548 million USD to only 0.5 million USD, and the volume was cut from 472 thousand tonnes to 98 tonnes. The import ban affected trade in all kinds of meat. This significant export reduction particularly affected the trade in pig meat and the trade in poultry meat. Pork meat trade was reduced from 1,548 million USD to 0,5 million USD. Poultry meat trade was reduced from 95 million USD to 32 ths. USD. For specific time period (2014 and beginning 2015), it even destabilized EU pork market. The most affected countries suffering because of applied ban for meat imports are Germany, Denmark, Spain, France the Netherlands, Poland. To compensate missing imports from the EU, Russia increased imports of meat from Brazil, Belarus, Turkey, Argentina, and Serbia. Because of constantly increasing re-exports from Serbia and Belarus, Russia decided to change its attitude to bilateral trade agreements.

The ban applied on fish imports did not affect EU trade performance so much as bans applied on other commodities imports. In period 2013-2016, the value of EU export was reduced from 216 million USD to cc 64 million USD. Trade volume was reduced from cc115 ths. tons to cc 24 ths. tons. In the case of fish trade the most affected country is not EU member. It is Norway.

Between 2013 and 2016, the applied ban reduced EU dairy exports to Russia from 1,738 million USD/year to cc 3 million USD/year. The exported volume was reduced 
from 417 ths. tons to only 620 tons. The most affected segments of dairy trade are the following: cheese and curd (export value reduction by 1,272 million USD), butter and milk fats (within analysed time period - the export value was reduced from 184 million USD to less than 100 ths. USD). Countries suffering by applied ban are especially Russian neighbours as Finland, Poland and Baltic countries. Russia substitute EU products by imports from especially the following countries Argentina, Belarus, and Kazakhstan (it is only re-export - it is evident especially in the case of Belarus).

\section{Conclusion}

The value of agricultural imports from affected countries was reduced by 12,598 million USD i.e. by $66 \%$ (between 2013 and 2016). The import from other countries was also reduced by 5,535 million USD i.e. by $22 \%$. Applied ban affected especially those imports which could be understand as competitors for national production capacities (meat and meat products, dairy and dairy products, fruit and vegetable, fish). The potential to substitute those items by local production is evident.

The applied ban significantly reduced especially imports of above-mentioned products by 13,100 million USD in period 2013-2016. Applied ban reduced imports from affected countries from 9.007 million USD to 742 million USD and from the rest of the world from 14,128 million USD to 9,293 million USD.

The most affected region (about the effect of Russian import ban) is the European Union. The applied ban affected imports especially from Lithuania, Germany, the Netherlands, Denmark, Spain, Belgium, Finland and France. Speaking about the most affected countries, in relation to the share of Russian imports in their trade performance, the most affected countries are Lithuania, Latvia, Estonia, Finland and Poland. In period 2013 - 2016, the value of EU imports affected by import ban was reduced from 6,525 million USD to only 683 million USD. Total agricultural EU exports to Russia decreased from more than 15.6 billion USD to less than 6 billion USD. Russian applied policy also affected non-banned items import and it reduced Russian food dependency in relation to the European Union.

In period 2013 - 2016 the value and volume of EU dairy exports was reduced by 1,734 million USD ie. 416 ths. tons, meat exports reduced their value and volume by 1,547 million USD respectively 472 ths. tons and fruits export were reduced by 1,449 million USD respectively 1498 ths. tons. Export reduction also affected vegetables and fish trade activities.

To satisfy domestic demand Russia increased food imports especially from Serbia, China, Azerbaijan, Ecuador, Kyrgyzstan, India, Macedonia, Georgia, Bosnia and Malaysia. The negative feature of applied ban especially for Russian consumers was the reduction of food heterogeneity, the growth of food price, the reduction of competitiveness and available food quality reduction.

The influenced of Russian import ban reduced mutual (EU - Russia) trade in affected commodities from 7.061 million USD/year in 2013 to only 1,429 million USD/year in 2016. 
Russian policy also affected EU exports of other food items. Speaking about not banned exports, their value was reduced from 6,495 million USD/year in 2013 to only 4,738 million USD/year in 2016. EU recorded also significant export reduction in these items: beverages and spirits, cut flowers, prepared animal fodder and tobacco products.

Acknowledgements. This paper is supported by a grant project of the Internal Grant Agency of the FEM CULS Prague. The project title is ,Influence of economic sanctions and embargo on agricultural sector in Russian Federation and European Union". Project n. 20181017.

\section{References}

1. Comtrade UN: Database, https://comtrade.un.org/data, last accessed 2018/07/14.

2. Erokhin, V., Ivolga, A., Heijman, W.: Trade Liberalization and State Support of Agriculture: Effects for Developing Countries. Agricultural Economics 60(11), 524-537 (2014), DOI: 10.17221/137/2013-AGRICECON.

3. Erokhin, V.: Factors Influencing Food Markets in Developing Countries: An Approach to Assess Sustainability of the Food Supply in Russia. Sustainability 9(8), 1-13 (2017), DOI: 10.3390/su9081313.

4. FAO UN: Russia's restrictions on imports of agricultural and food products: An initial assessment, http://www.fao.org/3/a-i4055e.pdf, last accessed 2018/10/10.

5. Federal Customs Service of Russia: Database, http://stat.customs.ru/apex/f?p=201:1:4414186153597292::NO, last accessed 2018/05/05.

6. Federal State Statistics Service of RF: Statistics, http://www.gks.ru/wps/wcm/connect/rosstat_main/rosstat/en/main, last accessed 2018/08/05.

7. Ishchukova, N., Smutka, L.: The Formation of Russian Agrarian Trade Structure. Interindustry vs. Intra-industry Trade Activities. Acta Universitatis Agriculturae et Silviculturae Mendelianae Brunensis 62(6), 1293-1299 (2014), DOI: 10.11118/actaun201462061293.

8. Kapsdorferová, Z., Sviridova, O.: Impact of sanctions on agricultural policy in European Union and Russia. In International Scientific days 2016 The Agri-Food Value Chain: Challenges for Natural Resources Management and Society, pp. 190-200. Slovak University of Agriculture in Nitra, Nitra (2016).

9. Kaštáková, E.: The Impact of Comparative Advantages in the Deepening Mutual Foreign Trade Relations between the Slovakia and Russia. Journal of Economics 60(7), 746-762 (2012).

10. Koptseva, N. P., Kirko, V. I.: Development of the Russian Economy's Agricultural Sector Under the Conditions of Food Sanctions (2015-2016). Journal of Environmental Management and Tourism 8(1), 123-131 (2017), DOI: 10.14505//jemt.v8.1(17).13.

11. Smutka, L., Špička, J., Ishchukova, N., Selby, R.: Agrarian import ban and its impact on the Russian and European Union agrarian trade performance. Agricultural Economics 62(11), 493-506 (2016), DOI: 10.17221/294/2015-AGRICECON.

12. Svatoš, M., Smutka, L., Ishchukova, N.: The Position of Agriculture in the Russian Federation - the Last Two Decades Development Overview. Agricultural Economics 60(11), 489-502 (2014), DOI: 10.17221/65/2014-AGRICECON. 
13. The Russian Government: Doctrine of Food Security of RF 2009, http://government.ru/docs/16916/, last accessed 2018/01/26. 